\title{
Kirschenmann Road Multi-Well Monitoring Site, Cuyama Valley, Santa Barbara County, California
}

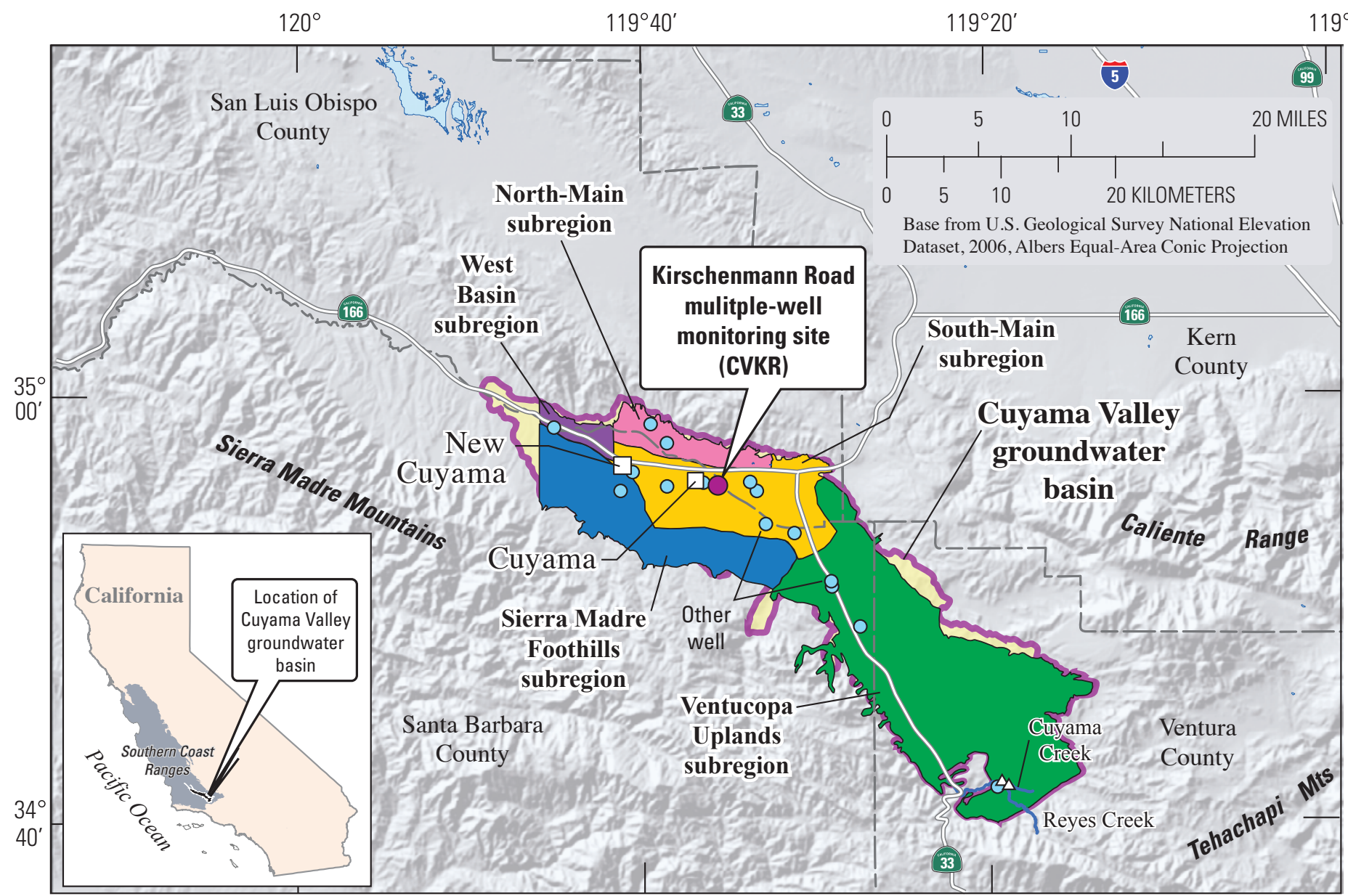

Figure 1. Location of multiple-aquifer monitoring-well site (CVKR), selected supply and irrigation wells, and surface-water water-quality collection sites Cuyama Creek and Reyes Creek, Cuyama Valley, California.

\section{Introduction}

The U.S. Geological Survey (USGS), in cooperation with the Water Agency Division of the Santa Barbara County Department of Public Works, is evaluating the geohydrology and water availability of the Cuyama Valley, California (fig. 1). As part of this evaluation, the USGS installed the Cuyama Valley Kirschenmann Road multiple-well monitoring site (CVKR) in the South-Main subregion of the Cuyama Valley (fig. 1). The CVKR well site is designed to allow for the collection of depth-specific water-level and water-quality data. Data collected at this site provides information about the geology, hydrology, geophysics, and geochemistry of the local aquifer system, thus, enhancing the understanding of the geohydrologic framework of the Cuyama Valley. This report presents the construction information and initial geohydrologic data collected from the CVKR monitoring site, along with a brief comparison to selected supply and irrigation wells from the major subregions of the Cuyama Valley (fig. 1).

\section{Well Completion}

The CVKR borehole was drilled to a depth of $1,003.5$ feet below land surface (ft bls) using direct mud-rotary drilling techniques. Drill cuttings were collected throughout the drilling process and a core sample was collected from the bottom of the borehole to determine the lithology (fig. 2). To assist in the identification of lithologic and stratigraphic units, geophysical logs were collected from the borehole prior to well construction in accordance with the protocols established by the USGS National Field Manual (U.S. Geological Survey, variously dated, book 2). Four 2-inch-diameter wells, were installed with screened intervals from 960 to 980 (CVKR-1), 760 to 780 (CVKR-2), 600 to 620 (CVKR-3), and 440 to 460 (CVKR-4) ft bls (fig. 2). A filter pack of \#3 sand was installed around each screen and a low-permeability bentonite grout was placed between the filter packs to vertically isolate each of the wells. Installation of multiple wells within a single borehole allows for analysis of the hydrologic properties of discrete vertical zones within the multiple-aquifer system as well as the collection of depth-specific water-quality samples. 

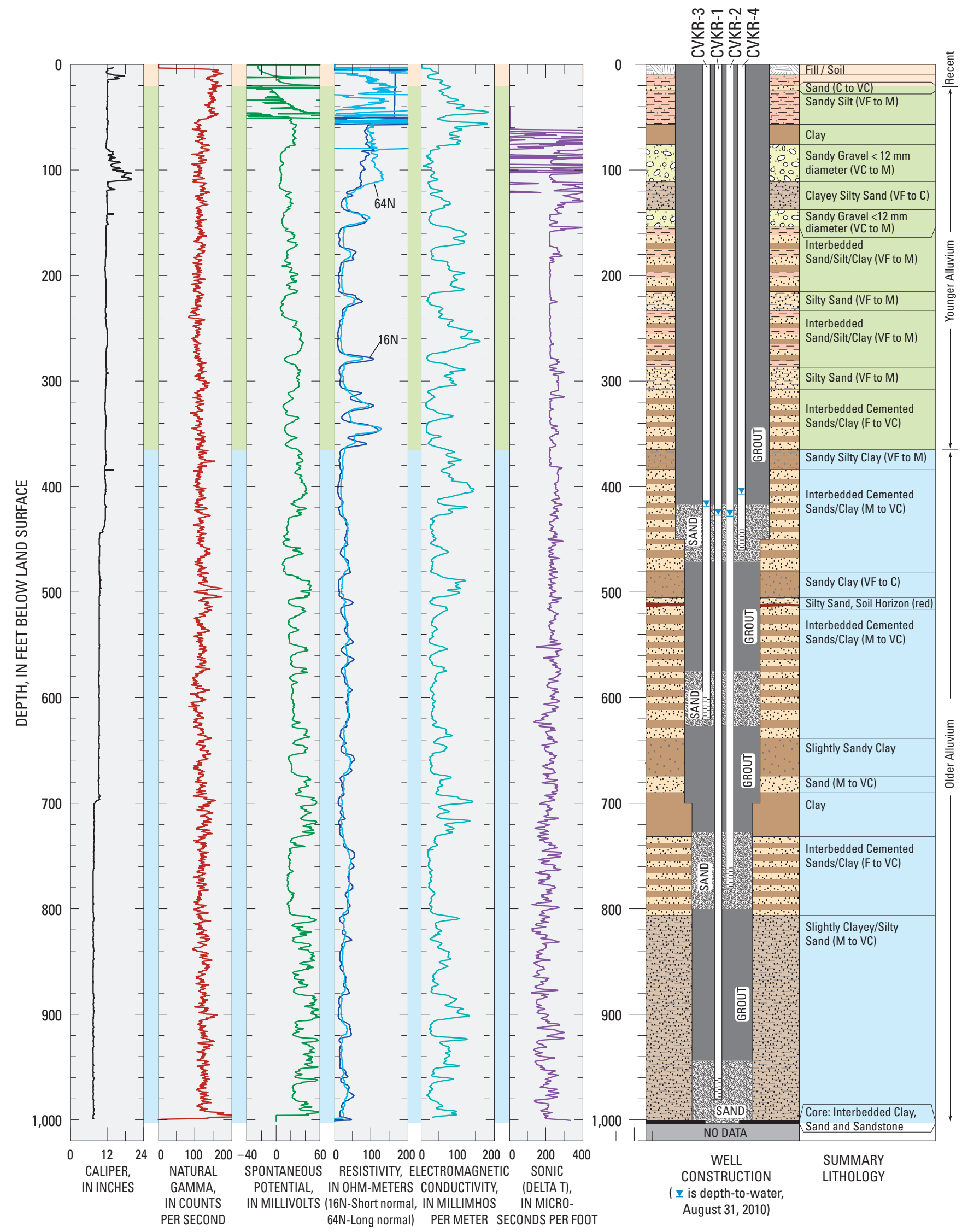

Figure 2. Well construction, summary lithology, and geophysicallog data from multiple-well monitoring site CVKR, Cuyama Valley,

California. Abbreviations: VF, very fine; F, fine; $M$, medium; $C$, coarse; $V C$, very coarse.

\section{Geology}

Singer and Swarzenski (1970) generalized the geology of the Cuyama Valley into four main units: (1) non-water-bearing rocks-the basement complex and all sedimentary rocks older than the Morales 


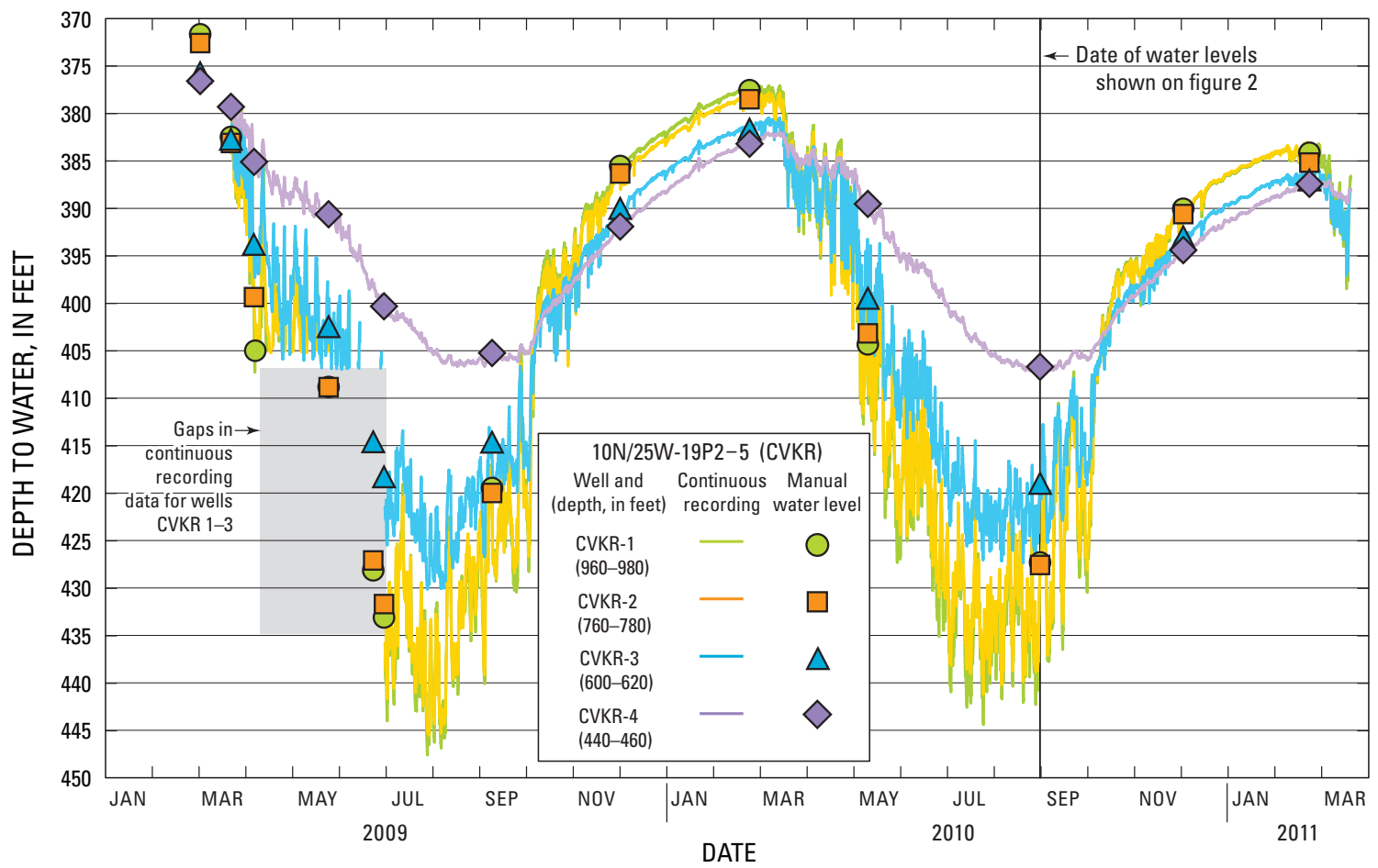

Figure 3. Water-level hydrograph from multiple-well monitoring site CVKR from March 1, 2009 to March 20, 2011, Cuyama Valley, California.

Formation, (2) the Morales Formation of Pleistocene to Pliocene age, (3) older alluvium of Pleistocene age, and (4) younger alluvium of Holocene age. Cross sections accompanying the geologic maps of Vedder and Repenning (1975), which were based, in part, on deep oil and gas exploration wells, show that older and younger alluvial deposits are generally about 1,000 feet thick in the vicinity of CVKR borehole. As evidenced by the drill cuttings and geophysical logs, the CVKR borehole penetrated terrestrial siliciclastic sediments that are alluvial fan and stream deposits (fig. 2). The borehole encountered younger alluvium from land surface to about $360 \mathrm{ft}$ bls and older alluvium from about $360 \mathrm{ft}$ bls to the bottom the hole. The Morales Formation was not encountered in this borehole. Sediments encountered in the CVKR borehole at intermediate depths of 360 to $620 \mathrm{ft}$ bls were much more consolidated than expected from the descriptions of these older alluvium units published on the geologic maps. Drill cuttings collected at about $505 \mathrm{ft}$ bls were reddish in color, suggesting the presence of a paleosol (buried soil horizon), which represents a period of non-deposition (fig. 2). The highest levels of natural gamma occur within, and just above, this paleosol. Below 720 feet there is a general decrease in sonic Delta $\mathrm{T}$, indicating an increase in cementation and induration. The three feet of core collected from the bottom of the borehole contained interbedded clay, sand, and sandstone.

\section{Hydrology}

Each of the four wells at the CVKR site was equipped with instrumentation to automatically measure and record the depth to water at regular time intervals (fig. 3). Periodic manual measurements of water levels were made to verify the continuously-monitored data (fig. 3). The pumping of nearby irrigation wells influenced water levels in all of the CVKR wells. Over the period of record (2009-2011), data showed a seasonal pattern, with water levels declining between March and August, coinciding with the peak of the agricultural season, and rising between September and February, when nearby irrigation and related pumping was at a minimum. Seasonal water levels in the three deeper wells (CVKR-1, 2 and 3) varied as much as 60 feet between March and August, while water levels in the shallowest well (CVKR-4) varied by about $25 \mathrm{ft}$ over the same period. Water levels showed a decline in the seasonally high levels over the period of record. Manual measurements made in late February of 2011 showed a decline of over 10 feet compared to those made in early March of 2009. Vertical water-level gradients were upward during the winter months and reversed to downward gradients during the irrigation season.

Slug tests were performed on each of the wells, in accordance with the protocols established by the USGS National Field Manual (U.S. Geological Survey, variously dated, book 3), to estimate the hydraulic conductivity of the aquifer material next to the screened interval. The shallowest well (CVKR-4) had the lowest estimated hydraulic conductivity value of 9.3 feet per day (ft/day), well CVKR-3 had the highest estimated hydraulic conductivity value of $28 \mathrm{ft} / \mathrm{day}$, and wells CVKR-2 and CVKR-1 had slightly lower values of 22 and $18.1 \mathrm{ft} /$ day, respectively.

\section{Geochemistry}

Water samples were collected in accordance with the protocols established by the USGS National Field Manual (U.S. Geological Survey, variously dated, book 9) and were analyzed for major-ion chemistry, stable isotopes of hydrogen (deuterium) and oxygen (oxygen-18), tritium, and carbon-14 to delineate the type, source, and age of the groundwater. Analyses were performed by the USGS National Water Quality Laboratory (NWQL) in Lakewood, Colorado; the USGS Stable Isotope Laboratory in Reston, Virginia; and the National Ocean Sciences AMS Facility in Woods Hole, Massachusetts, following standard methods outlined by Fishman (1993), Copland and others (1991), Ostlund and Dorsey (1977), and Coplen (1994).

The samples from the CVKR wells were found to be calciummagnesium-sulfate waters (fig. 4). Water-quality characteristics of all four samples were similar to each other and to samples from other wells in the South-Main subregion (fig. 1).

Nitrate concentrations, reported as nitrogen $\left(\mathrm{NO}_{3}-\mathrm{N}\right)$, in the shallow well (CVKR-4) were 15 milligrams per liter (mg/L); CVKR-3 had a $\mathrm{NO}_{3}-\mathrm{N}$ concentration of $7 \mathrm{mg} / \mathrm{L}$ (table 1). Irrigation return flows are a possible source of the high $\mathrm{NO}_{3}-\mathrm{N}$ concentrations in the shallower wells.

The stable isotopes oxygen-18 and deuterium in groundwater reflect the altitude, latitude, and temperature of recharge and the extent of evaporation before water entered the groundwater system. The isotope samples from the three deeper wells are progressively lighter (more negative), indicating that groundwater does not move freely between the different layers. Restricted movement of water between the layers also is supported by wide variation in isotope values in water from the other water-supply and irrigation wells in South-Main subregion. The three deeper CVKR wells are most similar to samples from the Sierra Madre and Ventucopa subregions (fig. 1), indicating that these subregions could be the main source of recharge for the SouthMain subregion. The isotopic composition of the sample from the 
Table 1. Selected water-chemistry constituents for the CVKR monitoring site, Cuyama Valley, California. Abbreviations: ND denotes no detection.

\begin{tabular}{|c|c|c|c|c|c|c|c|}
\hline $\begin{array}{c}\text { State and local well } \\
\text { number }\end{array}$ & $\begin{array}{l}\text { Screened } \\
\text { interval } \\
\text { (feet below } \\
\text { land } \\
\text { surface) }\end{array}$ & $\begin{array}{c}\text { Total } \\
\text { dissolved } \\
\text { solids } \\
\text { (milligrams } \\
\text { per liter) }\end{array}$ & $\begin{array}{l}\text { Nitrate plus } \\
\text { nitrite, as } \\
\text { nitrogen } \\
\text { (milligrams } \\
\text { per liter) }\end{array}$ & 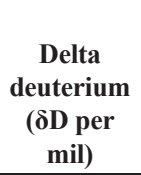 & $\begin{array}{c}\text { Delta } \\
\text { oxygen-18 } \\
\left(\delta^{18} \mathrm{O} \text { per }\right. \\
\text { mil })\end{array}$ & $\begin{array}{c}\text { Tritium } \\
\text { (picocuries } \\
\text { per liter }\end{array}$ & $\begin{array}{c}\text { Uncorrected } \\
\text { carbon-14 } \\
\text { age (years } \\
\text { before } \\
\text { present) }\end{array}$ \\
\hline 10N/25W-19P2 (CVKR-1) & $960-980$ & 1,580 & ND & -71.3 & -9.86 & ND & 6,300 \\
\hline 10N/25W-19P3 (CVKR-2) & $760-780$ & 1,500 & 0.54 & -70.8 & -9.92 & ND & 4,600 \\
\hline $10 \mathrm{~N} / 25 \mathrm{~W}-19 \mathrm{P} 4$ (CVKR-3) & $600-620$ & 1,560 & 7.0 & -69.3 & -9.64 & 0.3 & 3,700 \\
\hline 10N/25W-19P5 (CVKR-4) & $440-460$ & 1,820 & 15.2 & -66.3 & -9.52 & 0.5 & 3,600 \\
\hline
\end{tabular}

shallow well (CVKR-4) is similar to the composition of a surface-water sample collected from Cuyama Creek, indicating the creek could be the source of recharge for this subregion.

Tritium and carbon-14 are radioactive isotopes that provide information about the age (time since recharge) of groundwater. Water from the four CVKR wells contained low levels of tritium, ranging from 0 (non-detection) to 0.5 picocuries per liter. Samples from CVKR-3 and CVKR-4 had low tritium concentrations, indicating the presence of at least some recent recharge; however, the samples from CVKR-1 and CVKR-2 contained no detectable tritium, indicating that the water from these wells was recharged prior to the early $1950 \mathrm{~s}$. The uncorrected carbon-14 ages of the water collected from the wells increased with depth and ranged from 3,600 to 6,300 years before present (table 1). Water samples collected from other wells in the Cuyama Basin contained levels of carbon-14 representative of water recharged between 600 (Ventucopa Uplands) to 33,400 (Sierra Madre Foothills) years before present.

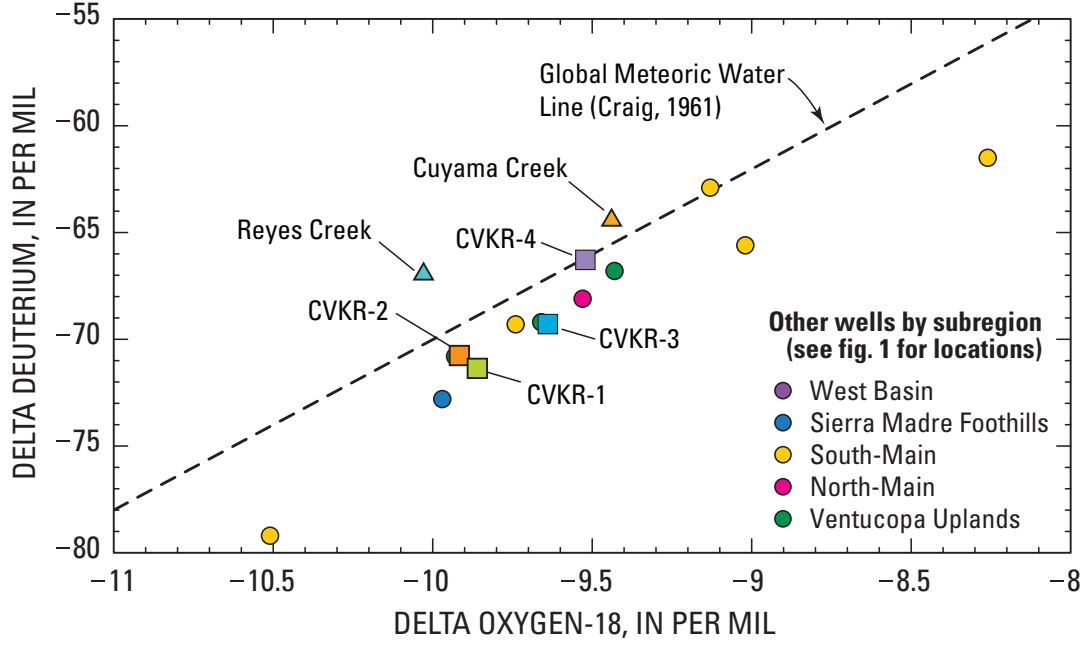

Figure 5. Isotopic composition of groundwater collected from multiple-well monitoring site CVKR, and selected water-supply and irrigation wells and surface water collected from Cuyama and Reyes Creeks, Cuyama Valley, California.

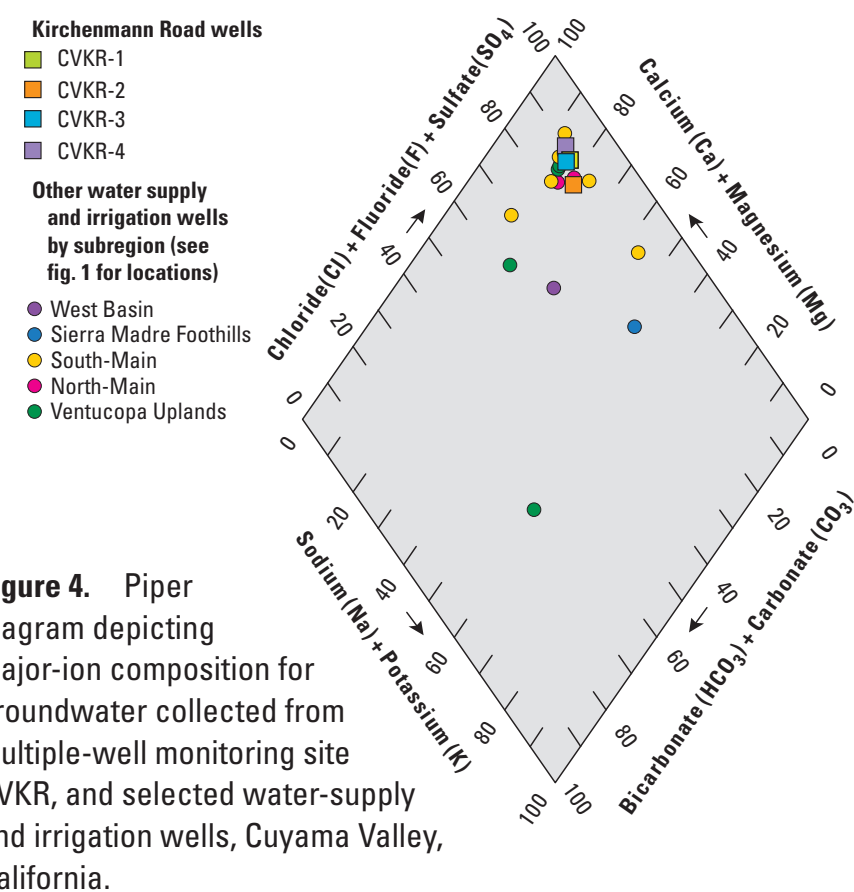

\section{References}

Coplen, T.B., 1994, Reporting of stable hydrogen, carbon, and oxygen isotopic abundances: Pure \& Applied Chemistry, v. 66, p. 273-276.

Coplen, T.B., Wildman, J.D., and Chen, J., 1991, Improvements in the gaseous hydrogen-water equilibration technique for hydrogen isotope ratio analysis: Analytical Chemistry, v. 63, p. 910-912

Craig, H., (1961). "Isotopic variations in meteoric waters". Science, 133, 1702-1703.

Fishman, M.J., ed., 1993, Methods of analysis by the U.S. Geological Survey National Water Quality Laboratory--Determination of inorganic and organic constituents in water and fluvial sediments: U.S. Geological Survey Open-File Report 93-125, $217 \mathrm{p}$

Ostlund, H.G. and Dorsey, H.G., 1977, Rapid electrolytic enrichment and hydrogen gas proportional counting of tritium, in Low-Radioactivity Measurements and Applications: Proceedings of the International Conference on Low-Radioactivity Measurements and Application, October 6-10, 1975, The High Tatras, Czechoslovakia, p. 55-60.

Singer, J.A., and Swarzenski, W.V., 1970, Pumpage and ground-water storage depletion in Cuyama Valley California, 1947-66: U.S. Geological Survey Open-File Report 70-304, 24 p

U.S. Geological Survey, variously dated, National field manual for the collection of water-quality data: U.S. Geological Survey Techniques of Water-Resources Investigations, books 2,3, and 9, available online at http://pubs.water.usgs.gov/twri/.

Vedder, J.G., and Repenning, C.A., 1975, Geologic map of the Cuyama and New Cuyama quadrangles, San Luis Obispo and Santa Barbara Counties, California: U.S. Geological Survey Miscellaneous Investigations Map I-876, scale 1:24,000.

By R.R. Everett, R.T. Hanson, and D.S. Sweetkind

Technical Contacts:

Rhett R. Everett

Randall T. Hanson

U.S. Geological Survey

4165 Spruance Road, Suite 200

San Diego, CA 92101
Don Sweetkind

U.S Geological Survey, Denver Federal Center, MS 973 Lakewood, CO 80225-0046 